\title{
A NOTE ABOUT NAMES
}

I refer to individuals by their nickname or first name, and in some cases their only name, as is common practice in Indonesia. I have also adhered to anthropological convention by using pseudonyms for most of the individuals in this book in order to protect their identities. However, in the instances where I rely upon archival sources, media sources, and select activist sources to discuss aspects of state violence and injustice, I refer to activists by their real name. Certain personalities from Generation 98 have achieved acclaim, status, and recognizability in Indonesia as a result of their activism and they too appear by name. My ethnography retains a contemporaneous relationship with work done in the fields of history, sociology, and political science, where the same individuals I discuss have already appeared in print as themselves. I consider the act of naming them a historicizing act of recognition for the efforts of individuals who continue to work in the public domain of Indonesian human rights, cultural politics, and democracy. 
